\title{
A review of spinal cord stimulation systems for chronic pain
}

\section{Paul Verrills' \\ Chantelle Sinclair ${ }^{2}$ \\ Adele Barnard ${ }^{2}$}

'Metro Pain Group, ${ }^{2}$ Monash Clinical Research, Monash House, Clayton, Victoria, Australia

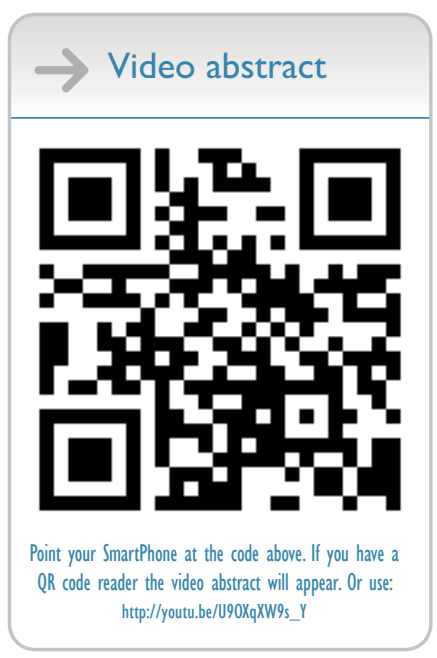

Correspondence: Chantelle Sinclair Monash Clinical Research, Monash House, 27I Clayton Rd, Clayton, Victoria, 3168, Australia

Tel +61395956180

Fax +6I 395956110

Email: csinclair@monashcr.com.au

\author{
This article was published in the following Dove Press journal: \\ Journal of Pain Research \\ I July 2016 \\ Number of times this article has been viewed
}

\begin{abstract}
Spinal cord stimulation (SCS) applications and technologies are fast advancing. New SCS technologies are being used increasingly in the clinical environment, but often there is a lag period between the clinical application and the publishing of high-quality evidence on safety and efficacy. Recent developments will undoubtedly expand the applicability of SCS, allowing more effective and individualized treatment for patients, and may have the potential to salvage patients who have previously failed neuromodulation. Already, high-level evidence exists for the safety, efficacy, and cost-effectiveness (Level I-II) of traditional SCS therapies in the treatment of chronic refractory low back with predominant limb pain (regardless of surgical history). More than half of all patients with chronic painful conditions experience sustained and significant levels of pain reduction following SCS treatment. Although only limited evidence exists for burst stimulation, there is now Level I evidence for both dorsal root ganglion SCS and high-frequency SCS that demonstrates compelling results compared with traditional therapies. The body of evidence built on traditional SCS research may be redundant, with newer iterations of SCS therapies such as dorsal root ganglion SCS, high-frequency SCS, and burst SCS. A number of variables have been identified that can affect SCS efficacy: implanter experience, appropriate patient selection, etiologies of patient pain, existence of comorbidities, including psychiatric illness, smoking status, and delay to SCS implant following pain onset. Overall, scientific literature demonstrates SCS to be a safe, effective, and drug-free treatment option for many chronic pain etiologies.
\end{abstract}

Keywords: spinal cord stimulator, neuromodulation, chronic pain, low back pain

\section{Introduction to chronic pain}

Chronic pain affects up to $20 \%$ of the population in developed nations. ${ }^{1-4}$ This represents a profound impact on individuals and their families alongside the sizeable burden on employers, health care systems, and society in general. ${ }^{3}$ When chronic pain occurs, it has the potential to become disease itself, and subsequently, chronic pain has emerged as a distinct phenomenon. ${ }^{5}$

Management of chronic pain varies greatly between nations and even within nations. Literature supports a multidisciplinary approach as the standard of care, although various health care systems may not always support this concept consistently. ${ }^{2}$

The current standard of care for chronic, noncancer pain typically includes many disciplines with the clinician developing an individualized treatment plan with the options of utilizing surgical interventions, pharmacology, and psychological and physical therapies. Opioid analgesics are often prescribed, despite the lack of clinical 
evidence supporting their long-term use in the management of chronic pain. ${ }^{6}$ However, for many patients, this multidisciplinary approach is inadequate or ineffectual or is accompanied by the burden of side effects that are unacceptable and debilitating. Only at this late stage, referral for advanced neuromodulation techniques is considered and potentially trialed.

\section{Neuromodulation}

The field of neuromodulation for the treatment of pain has developed rapidly since the seminal paper on the electrical inhibition of pain by the stimulation of the dorsal column almost 50 years ago. ${ }^{7}$ The original term of dorsal column stimulation has evolved to become known as spinal cord stimulation (SCS). ${ }^{8}$ SCS has been particularly effective as an adjunct in treating mixed neuropathic/nociceptive and neuropathic/radicular pain conditions such as failed back surgery syndrome (FBSS) and complex regional pain syndrome (CRPS). Neuromodulation therapies offer a treatment option that has minimal side effects and that is relatively safe and potentially reversible. ${ }^{9}$ SCS has been used to treat various pain conditions for many decades. . $^{810-13}$

In traditional SCS therapies, the objective has been to replace the pain sensation with paresthesia that requires mapping of stimulation to the region of pain. ${ }^{14}$ The anticipation is that the electrical current alters pain processing by masking the sensation of pain with a comfortable tingling or paresthesia. Although patients mostly cope with paresthesia, a significant proportion report that the sensation is unpleasant, particularly with positional changes.

The stimulation is provided either through electrodes that are placed percutaneously into the epidural space or through a surgical paddle lead that is delivered via a laminotomy. ${ }^{8}$ These devices are capable of delivering pulse frequencies in the range of 2-1,200 $\mathrm{Hz}$ but are regularly utilized at $40-60 \mathrm{~Hz}$.

Patients typically undergo a trial of neuromodulation with an externalized power source and if this trial proves to be positive and compelling, they subsequently have a subcutaneously implantable pulse generator for the long-term therapy.

In recent years, the next phase in the evolution of neuromodulation has become available with the development of dorsal root ganglion (DRG) SCS and the emerging use of two novel advances in stimulation frequencies, being highfrequency SCS (at 10,000 Hz) and burst SCS. ${ }^{14-19}$ These recent advances have improved the efficacy and expanded the applicability of SCS.

DRG SCS is a highly targeted form of neuromodulation therapy. ${ }^{20}$ Studies indicate that the DRG plays a key role in both nociceptive and neuropathic pain. ${ }^{14,21}$ DRG SCS is particularly useful in treating focal areas of pain, in particular those that have been difficult to target with traditional SCS systems such as groin and foot pain, by applying an innovative lead configuration and delivery system around the DRG. ${ }^{8,9,15}$

High-frequency 10 SCS (HF10) presents a significant development in the evolution of SCS technologies. ${ }^{19}$ This involves application of a unique waveform at $10,000 \mathrm{~Hz}$ at a subthreshold level and therefore provides pain relief without any paresthesia. ${ }^{18,22}$ The majority of patients have a clear preference for paresthesia-free stimulation, and HF10 has been approved for clinical use in Australia and Europe since 2011 and has received Food and Drug Administration approval for the United States in 2015 for patients with chronic refractory pain of the trunk and/or limbs. ${ }^{22,23}$

Burst SCS offers another novel mode of stimulation whereby conventional frequency parameters are provided in bursts of five pulses. The burst frequency is $40 \mathrm{~Hz}$, and the pulse frequency is $500 \mathrm{~Hz}$. Amplitude is reduced to try and achieve subthreshold stimulation, thereby providing pain relief with either reduced or no paresthesia. ${ }^{16,17,24}$

\section{Efficacy}

The most recent systematic and comprehensive review of the effectiveness of SCS in treating chronic spinal pain demonstrated that there is a significant (Level I-II) evidence for SCS as a treatment for lumbar FBSS, where conventional medical management has failed. ${ }^{23}$ Furthermore, there is now Level I evidence for high-frequency stimulation but only limited evidence for burst stimulation. ${ }^{23}$

In another recent and extensive review and meta-analysis of conventional SCS, more than half of all patients experienced significant pain relief. ${ }^{25}$ The authors observed that this was maintained for a mean follow-up period of 24 months. ${ }^{25}$ These reviews demonstrate that traditional SCS is an effective treatment option for a cohort that is notoriously difficult to treat.

The existing SCS literature has a large number of case series reports and only a limited number of high-quality, large prospective, consecutively recruited, randomized, or controlled comparative trials (Table 1). ${ }^{8,23,25}$ Furthermore, the literature, when viewed historically, must be tempered by the developments in skills, application, and technological advances. ${ }^{26}$ Hence, the traditional SCS papers have often reported successful pain relief as an undifferentiated generic pain that is not specific to the site of the primary or greatest pain (eg, back or leg). ${ }^{25}$ This observation is important because conventional SCS therapy has historically been prescribed 
Table I Selection of SCS literature with focus on back \pm lower limb pain studies

\begin{tabular}{|c|c|c|c|c|}
\hline Study & Year & $\begin{array}{l}\text { Design, cohort, sample } \\
\text { size, follow-up }\end{array}$ & Reported findings & Comments \\
\hline $\begin{array}{l}\text { Barolat } \\
\text { et al }{ }^{28}\end{array}$ & 2001 & $\begin{array}{l}\text { Prospective, multicenter } \\
\text { observational case series } \\
\mathrm{n}=4 \mathrm{I} \\
\text { Follow-up: I year } \\
\text { Cohort: back and leg pain } \\
\text { (with predominant pain in } \\
\text { back) }\end{array}$ & $\begin{array}{l}\text { Tests SCS systems with paddle electrodes } \\
\text { and RF stimulator } \\
n=I 5 \text { at I year } \\
\text { At } 12 \text { months, } 88 \% \text { of patients reported } \\
\text { fair-excellent pain relief for leg pain } \\
\text { following SCS } \\
\text { At } 12 \text { months, } 68 \% \text { of the patients reported } \\
\text { fair-excellent pain relief for back pain } \\
\text { following SCS }\end{array}$ & $\begin{array}{l}\text { Groups pain relief of fair to excellent into one } \\
\text { group } \\
\text { Three patients dropped from study at } 6 \\
\text { months: two due to inadequate pain relief } \\
\text { and one classified as technical failure because } \\
\text { power required to induce satisfactory } \\
\text { paresthesia to control pain was inadequate. } \\
\text { This methodology skews the outcome data }\end{array}$ \\
\hline $\begin{array}{l}\text { Kemler } \\
\text { et al }{ }^{58}\end{array}$ & 2004 & $\begin{array}{l}\text { RCT } \\
\mathrm{n}=54 \text { ( } 36 \text { randomized to } \\
\text { SCS + PT; } 18 \text { randomized to } \\
\text { PT only) } \\
\text { Follow-up: } 2 \text { years } \\
\text { Cohort: CRPS }\end{array}$ & $\begin{array}{l}\text { Tests either SCS + PT or PT only } \\
\text { Significant improvement for those receiving } \\
\text { SCS + PT: VAS mean improvement of } 2.1 \\
\text { versus } 0 \mathrm{~cm} \text { for PT only } \\
\text { Global perceived effect scale of } 43 \% \text { for } \\
\text { SCS + PT group versus } 6 \% \text { for PT only }\end{array}$ & $\begin{array}{l}\text { Complications for } 38 \% \text { of patients, occurring } \\
\text { mostly in first } 12 \text { months }\end{array}$ \\
\hline $\begin{array}{l}\text { North } \\
\text { et } \mathrm{al}^{59}\end{array}$ & 2005 & $\begin{array}{l}\text { Prospective } \\
\mathrm{RCT} \\
\text { (with optional cross over). } \\
\mathrm{n}=50 \\
\text { Follow-up average of } 3 \text { years } \\
\text { Cohort: FBSS }\end{array}$ & $\begin{array}{l}\text { Tests either reoperation or SCS: } \\
52 \% \text { of patients receiving (through cross } \\
\text { over or by randomization) SCS reported } \\
\text { long-term success, compared with 19\% } \\
\text { receiving (through cross over or by } \\
\text { randomization) reoperation. } \\
\text { SCS is more successful than reoperation for } \\
\text { treating radicular pain }\end{array}$ & $\begin{array}{l}\text { Excluded patients with primary or significant } \\
\text { back pain } \\
\text { Reoperation success rates tie with record low } \\
\text { reported in literature } \\
\text { Cross overs were counted as an } \\
\text { outcome measure (ITT analysis questions } \\
\text { this approach). Furthermore, despite some } \\
\text { reoperation patients meeting successful } \\
\text { outcome benchmark, they chose to cross } \\
\text { over in an attempt to try and gain even further } \\
\text { pain relief }\end{array}$ \\
\hline $\begin{array}{l}\text { Kumar } \\
\text { et } \mathrm{al}^{56}\end{array}$ & 2008 & $\begin{array}{l}\text { Prospective } \\
\mathrm{RCT} \\
\mathrm{n}=100 \text { ( } 52 \text { randomized to } \\
\mathrm{SCS}, 48 \text { randomized to } \\
\mathrm{CMM} \text { ) } \\
\text { Follow-up: } 2 \text { years } \\
\text { Multicenter (across } 12 \\
\text { centers internationally) } \\
\text { Cohort: FBSS patients }\end{array}$ & $\begin{array}{l}\text { Tests either SCS + CMM or CMM only: } \\
\mathrm{n}=42 \text { receiving stimulation at } 2 \text { years } \\
\text { experienced significantly lower levels of leg } \\
\text { pain but reported no difference in back pain } \\
\text { SCS treatment led to better outcomes when } \\
\text { measured using ODI, QOL, and patient } \\
\text { satisfaction measures } \\
\text { Analgesic intake and nondrug therapies did } \\
\text { not change with either treatment }\end{array}$ & $\begin{array}{l}45 \% \text { experienced complications, } 31 \% \text { required } \\
\text { surgical revision } \\
\text { Authors comment that if data are managed in } \\
\text { statistically conservative manner, then } 33 \% \text { of } \\
\text { patients receiving SCS will have significantly } \\
\text { less leg pain } \\
\text { Comparative group receiving CMM but not } \\
\text { placebo-controlled group }\end{array}$ \\
\hline \multirow[t]{3}{*}{$\begin{array}{l}\text { Turner } \\
\text { et al }{ }^{60,61}\end{array}$} & 2010 & $\begin{array}{l}\text { Prospective, controlled } \\
\text { cohort study } \\
\text { SCS trial, } n=51 \text {; } \\
\text { multidisciplinary PC } n=39 ; \\
\text { UC, } n=68 \\
\text { Follow-up at } 6,12 \text {, and } 24 \\
\text { months } \\
\text { Cohort: workers } \\
\text { compensation recipients with } \\
\text { FBSS }\end{array}$ & $\begin{array}{l}\text { Tests SCS against UC and a } \\
\text { multidisciplinary PC } \\
\text { At } 6 \text { months, SCS patients had } \\
\text { greater improvement in leg pain and function } \\
\text { but with concomitant higher rates of opioid } \\
\text { use } \\
\text { At } 12 \text { and } 24 \text { months, the groups did not } \\
\text { differ in rates of clinically meaningful leg pain } \\
\text { of function or in work status }\end{array}$ & $\begin{array}{l}\text { Study among very specific cohort/patient } \\
\text { subpopulation } \\
\text { Workcover patients could only receive SCS if } \\
\text { they joined study } \\
\text { SCS > PC and UC } \\
\text { Baseline pain } \\
\text { Baseline Roland-Morris Disability } \\
\text { Duration of pain } \\
\text { Time in WC claim system }\end{array}$ \\
\hline & & & Within 18 months, $19 \%$ had SCS removed & $\begin{array}{l}<25 \% \text { of SCS patients received psych } \\
\text { assessment/screening } \\
\text { SCS conversion rate was } 58 \% \text {, significantly } \\
\text { lower than that reported in literature }\end{array}$ \\
\hline & & & & $\begin{array}{l}\text { Implanter experience unclear } \\
\text { No comparative or alternative population } \\
\text { treated alongside WC group to act as control } \\
\text { group }\end{array}$ \\
\hline
\end{tabular}


Table I (Continued)

\begin{tabular}{|c|c|c|c|c|}
\hline Study & Year & $\begin{array}{l}\text { Design, cohort, sample } \\
\text { size, follow-up }\end{array}$ & Reported findings & Comments \\
\hline $\begin{array}{l}\text { De Vos } \\
\text { et } \mathrm{al}^{62}\end{array}$ & 2012 & $\begin{array}{l}\text { Prospective, observational } \\
\text { case series } \\
\mathrm{n}=4 \mathrm{I} \\
\text { Follow-up: } 12 \text { months } \\
\text { Cohort: FBSS }\end{array}$ & $\begin{array}{l}\text { Tests paddle-shaped SCS lead efficacy in } \\
\text { capturing both back and leg pain } \\
\text { Baseline leg pain mean of } 8 \text {, dropped to } \\
3.2 \text {, and baseline low back pain mean of } 7.5 \text {, } \\
\text { dropped to } 4.2 \text { at } 12 \text { months } \\
71 \% \text { experienced }>50 \% \text { pain relief for legs } \\
\text { and } 51 \% \text { of patients experienced }>50 \% \text { pain } \\
\text { relief for back }\end{array}$ & $\begin{array}{l}\text { By } 12 \text { months, } n=6 \text { reported no or minimal } \\
\text { pain relief, postulated that the FBSS and } \\
\text { treatment thereof masked pain of different } \\
\text { etiologies such as OA } \\
\text { No control group }\end{array}$ \\
\hline $\begin{array}{l}\text { Moriyama } \\
\text { et al }{ }^{63}\end{array}$ & 2012 & $\begin{array}{l}\text { Prospective, observational, } \\
\text { multicenter, open-label case } \\
\text { series } \\
\mathrm{n}=55 \\
\text { Follow-up: } 6 \text { months } \\
\text { Cohort: CRPS, FBSS, and } \\
\text { PVD }\end{array}$ & $\begin{array}{l}\text { Tests that patients likely to benefit from SCS } \\
\mathrm{n}=29 \text { at } 6 \text {-month follow-up where the overall } \\
\text { VAS mean baseline of } 74 \mathrm{~mm} \text { dropped to } \\
29.7 \mathrm{~mm} \\
\text { CRPS and PVD cases responding better than } \\
\text { FBSS patients }\end{array}$ & \\
\hline $\begin{array}{l}\text { Geurts } \\
\text { et } \mathrm{al}^{26}\end{array}$ & 2013 & $\begin{array}{l}\text { Prospective, observational, } \\
\text { consecutive case series } \\
\mathrm{n}=84 \\
\text { Follow-up at min } 0.2 \text { to } \max \\
\text { II.9 years } \\
\text { Cohort: CRPS-I }\end{array}$ & $\begin{array}{l}\text { Tests long-term treatment efficacy of SCS for } \\
\text { CRPS-I } \\
n=79 \\
41 \% \text { of patients experience } \geq 30 \% \text { pain relief } \\
\text { at endpoint } \\
\text { Pain relief stabilizes and holds over time } \\
\text { Having }<50 \% \text { pain relief at SCS trial was } \\
\text { a highly significant indicator of long-term } \\
\text { treatment failure }\end{array}$ & $\begin{array}{l}\text { Treatment success defined as } \geq 30 \% \text { pain relief } \\
\text { on baseline rather than } \geq 50 \% \\
\text { Minor common complications: lead migration } \\
\text { in } 23 \text { patients, seven experience hardware } \\
\text { malfunction requiring surgical intervention, } \\
\text { seven infections, } 44 \text { battery replacements } \\
\text { (mean battery life of } 4.4 \text { years). Data may } \\
\text { reflect outmoded hardware/technologies used } \\
\text { at start of trial } \\
\text { No major complications }\end{array}$ \\
\hline $\begin{array}{l}\text { Van Buyten } \\
\text { et } \text { al }^{18}\end{array}$ & 2013 & $\begin{array}{l}\text { Prospective, multicenter, } \\
\text { open-label, observational } \\
\text { study } \\
\mathrm{n}=83 \\
\text { Follow-up: } 6 \text { months } \\
\text { Cohort: majority FBSS ( } 81 \%) \text {, } \\
\text { predominantly low back pain }\end{array}$ & $\begin{array}{l}\text { Tests safety and efficacy of HF SCS } \\
\mathrm{n}=72 \text { proceed to implant } \\
\text { Back pain: mean VAS from } 8.4 \text { to } 2.7 \text { at } 6 \\
\text { months } \\
\text { Leg pain: mean VAS from } 5.4 \text { to } 1.4 \text { at } 6 \\
\text { months } \\
74 \% \text { had } \geq 50 \% \text { back pain relief at } 6 \text { months } \\
\text { Subset of I } 4 \text { had previously failed } \\
\text { conventional SCS. HFI0 able to capture or } \\
\text { rescue eleven of these with good results }\end{array}$ & $\begin{array}{l}\text { Note the use of both statistical mean and } \\
\text { median. Mean baseline VAS scores reported } \\
\text { but then median \% change in pain was reported. } \\
\text { No comparative group/control group - use of } \\
\text { baseline for control }\end{array}$ \\
\hline $\begin{array}{l}\text { Al-Kaisy } \\
\text { et } \mathrm{al}^{64}\end{array}$ & 2014 & $\begin{array}{l}\text { Prospective, multicenter, } \\
\text { observational case series } \\
\mathrm{n}=72 \\
\text { Follow-up: } 24 \text { months } \\
\text { Cohort: chronic unresponsive } \\
\text { LBP (I7\% previously failed } \\
\text { conventional SCS) }\end{array}$ & $\begin{array}{l}\text { Tests safety and long-term efficacy of HF SCS } \\
\text { on back and leg pain } \\
\mathrm{n}=65 \text { at } 24 \text {-month follow-up } \\
\text { Significant pain relief sustained } \\
\text { Back pain: mean VAS from } 8.4 \text { to } 3.3 \text { at } \\
2 \text { years ( } P \leq 0.00 \mathrm{I} \text { ) } \\
\text { Leg pain: mean VAS from } 5.4 \text { to } 2.3 \text { ( } P \leq 0.00 \text { I) } \\
\text { HF SCS is safe treatment } \\
60 \% \text { had } \geq 50 \% \text { back pain relief at } 24 \text { months }\end{array}$ & Observational study only \\
\hline $\begin{array}{l}\text { De Ridder } \\
\text { et } \mathrm{a}^{65}\end{array}$ & 2015 & $\begin{array}{l}\text { Retrospective, multicenter, } \\
\text { comparative trial } \\
\mathrm{n}=102 \\
\text { Follow-up: } 2 \text { weeks } \\
\text { Cohort: majority FBSS and } \\
\text { diabetic neuropathic pain. } \\
\text { All patients had been using } \\
\text { conventional SCS for at least } \\
6 \text { months }\end{array}$ & $\begin{array}{l}\text { Tests efficacy of novel burst stimulation SCS } \\
\text { against tonic/conventional SCS } \\
\text { Overall burst stimulation had significantly } \\
\text { better pain suppression over tonic } \\
\text { stimulation: back pain was suppressed } 29 \% \\
\text { better and limb pain } 31 \% \text { better when } \\
\text { compared with tonic stimulation } \\
\text { burst SCS able to "rescue" } 62 \% \text { of patients } \\
\text { who no longer responded to tonic stimulation }\end{array}$ & $\begin{array}{l}\text { No control group } \\
\text { All participants were acclimated to } \\
\text { conventional SCS prior to trial } \\
\text { Very short 2-week study period }\end{array}$ \\
\hline
\end{tabular}




\begin{tabular}{|c|c|c|c|c|}
\hline Study & Year & $\begin{array}{l}\text { Design, cohort, sample } \\
\text { size, follow-up }\end{array}$ & Reported findings & Comments \\
\hline \multirow[t]{7}{*}{$\begin{array}{l}\text { Kapural } \\
\text { et a }\left.\right|^{22}\end{array}$} & \multirow[t]{7}{*}{2015} & $\begin{array}{l}\text { Prospective, multicenter RCT } \\
\mathrm{n}=198 \\
\text { Follow-up: } 12 \text { months }\end{array}$ & $\begin{array}{l}\text { Tests safety and efficacy of conventional } \\
\text { versus HF SCS }\end{array}$ & $\begin{array}{l}\text { Subjects and investigators could not be } \\
\text { masked due to the nature of conventional SCS } \\
\text { treatment }\end{array}$ \\
\hline & & \multirow[t]{6}{*}{$\begin{array}{l}\text { Cohort: chronic back } \pm \text { leg } \\
\text { pain }\end{array}$} & $\begin{array}{l}n=|7| \text { successful trial and implanted. } \\
\text { Randomized I:I. } N=90, H F ; \text { and } n=8 I \text {, } \\
\text { conventional SCS. Equally safe }\end{array}$ & $\begin{array}{l}\text { Note the application of } \geq 40 \% \text { rather than } \\
\geq 50 \% \text { reduction in back pain as eligibility } \\
\text { measure for proceeding to implant }\end{array}$ \\
\hline & & & $\begin{array}{l}\text { HF SCS therapy subjects did not experience } \\
\text { paresthesia }\end{array}$ & $\begin{array}{l}\text { Used } \geq 50 \% \text { pain reduction for assessing } \\
\text { outcome measures }\end{array}$ \\
\hline & & & $\begin{array}{l}\text { The mean pre HF SCS VAS was } 7.4,12 \\
\text { months post HF SCS the mean VAS was } 2.5 \\
\text { ( } 67 \% \text { decrease): conventional SCS } 7.8 \text { to } 4.3 \\
\text { ( } 44 \% \text { decrease) }\end{array}$ & $\begin{array}{l}\text { HF SCS recharged daily, whereas conventional } \\
\text { typically had longer recharge intervals }\end{array}$ \\
\hline & & & $\begin{array}{l}\text { Mean leg pain HF SCS pre } 7 . I \text { to } 2 . I(70 \% \\
\text { decrease), conventional SCS } 7.6 \text { to } 3.8(49 \% \\
\text { decrease) }\end{array}$ & Patients naive to SCS of any form \\
\hline & & & $\begin{array}{l}\text { Remitter N pain scores } \leq 2.5 \text { VAS at } 12 \\
\text { months } \\
\text { Mean back pain: HF SCS: } 68.5 \% \text { versus } \\
\text { conventional SCS } 36.3 \% \text {. Mean leg pain: } \\
\text { HF SCS } 67.4 \% \text { versus conventional SCS } 42.5 \%\end{array}$ & \\
\hline & & & $\begin{array}{l}\text { Both the forms of SCS are safe and effective } \\
\text { but HF is significantly more effective }\end{array}$ & \\
\hline \multirow[t]{4}{*}{$\begin{array}{l}\text { Russo } \\
\text { et } \mathrm{al}^{29}\end{array}$} & \multirow[t]{4}{*}{2015} & $\begin{array}{l}\text { Retrospective, multicenter, } \\
\text { observational case series } \\
\mathrm{n}=256 \\
\text { Follow-up: } 6 \text { months }\end{array}$ & $\begin{array}{l}\text { Tests efficacy of HF SCS in real world/routine } \\
\text { clinical practice } \\
n=186 \text { permanent implant }\end{array}$ & $\begin{array}{l}\text { Authors acknowledge that uncontrolled } \\
\text { real-world application of SCS is different } \\
\text { in controlled studies and therefore carries } \\
\text { weaknesses such as no control group but }\end{array}$ \\
\hline & & $\begin{array}{l}\text { Cohort: range of chronic } \\
\text { pain diagnoses, including back } \\
\text { only, back }+ \text { limb, head } \pm\end{array}$ & $\begin{array}{l}\text { Overall, } \sim 50 \% \text { reduction in pain from baseline } \\
\text { was sustained for } 6 \text { months. Back } \pm \text { leg pain } \\
\text { responded best }\end{array}$ & $\begin{array}{l}\text { alternatively offers insights into clinical } \\
\text { experience }\end{array}$ \\
\hline & & neck, complex pain patterns. & & Wide variation in indications \\
\hline & & $\begin{array}{l}30 \% \text { of cohort had previously } \\
\text { failed conventional SCS }\end{array}$ & $\begin{array}{l}\text { Able to "rescue" majority of patients who } \\
\text { had previously failed conventional SCS }\end{array}$ & \\
\hline \multirow[t]{3}{*}{ Liem et $\mathrm{al}^{15}$} & \multirow[t]{3}{*}{2015} & $\begin{array}{l}\text { Prospective, multicenter, } \\
\text { open-labeled observational } \\
\text { study } \\
n=5 \text { I }\end{array}$ & $\begin{array}{l}\text { Tests DRG SCS as a treatment for } \\
\text { neuropathic pain } \\
n=32 \text { permanent implant }\end{array}$ & $\begin{array}{l}\text { No comparative/control group: observational } \\
\text { study only. Authors used patient baseline } \\
\text { measure as control }\end{array}$ \\
\hline & & $\begin{array}{l}\text { Follow-up: I } 2 \text { months } \\
\text { Cohort: several diagnoses, } \\
\text { including FBSS, CRPS, } \\
\text { radiculopathy, and lumbar }\end{array}$ & $\begin{array}{l}\text { Overall pain reduced by } 56 \% \text { at } 12 \text { months } \\
\text { and } 60 \% \text { of patients reported } \geq 50 \% \\
\text { improvement in pain }\end{array}$ & Relatively high incidence of adverse events \\
\hline & & stenosis & $\begin{array}{l}\text { Pain localized to back was reduced by } 42 \% \\
(n=10) \text {, leg pain reduced by } 62 \%(n=20) \text {, and } \\
\text { foot pain reduced by } 80 \%(n=10)\end{array}$ & \\
\hline
\end{tabular}

Notes: Only studies with larger sample sizes and those published after 2000 were included. Adapted from Taylor RS, Desai MJ, Rigoard P, Taylor RJ. Predictors of pain relief following spinal cord stimulation in chronic back and leg pain and failed back surgery syndrome: a systematic review and meta-regression analysis. Pain Pract. 2014;14(6):489-505. With permission from John Wiley and Sons, copyright $\odot 2013 .^{25}$

Abbreviations: CMM, conventional medical management; CRPS, complex regional pain syndrome; DRG, dorsal root ganglion; FBSS, failed back surgery syndrome; HF, high frequency; ITT, intention-to-treat; min, minimum; max, maimum; OA, osteoarthritis; ODI, Oswestry disability index; PC, pain clinic; PT, physical therapy; PVD, peripheral vascular disease; QOL, quality of life; RCT, randomized controlled trial; RF, radio frequency; SCS, spinal cord stimulation; UC, usual care; VAS, visual analog scale; WC, workers compensation; LBP, low back pain.

for limb pain and has had only limited success in managing back pain. ${ }^{10,27-29}$ Indeed, predominant back pain has been an exclusionary factor in many studies. ${ }^{25}$ Recent studies that have included back pain as the primary source have involved
HF10 therapy at $10,000 \mathrm{~Hz}$; this therapy has evolved to better capture significant back, leg, and radicular pain. ${ }^{10,22}$

Tolerance to SCS has been observed in patients where pulse amplitude needs to be increased to achieve the same 
analgesic benefit over time and/or efficacy has been lost. ${ }^{30,31}$ Tolerance cannot be predicted, and although the rate has not been widely reported in the literature, one study that researched over 10 years found it to be in the order of $29 \%{ }^{32}$ Possible causes for stimulation tolerance include neuroplasticity of pain transmission pathways, cellular or fibrotic changes in the tissues around the electrodes, patients reframing their pain over time, and psychological or psychiatric affective disorders. ${ }^{30}$ However, data pertaining to HF10 SCS have demonstrated no tolerance at this point. ${ }^{22}$

Despite strict criteria for patient selection, a substantial number of patients fail to achieve optimal pain relief with SCS. ${ }^{30,33}$ A number of factors have been identified as possible indicators for treatment failure including tobacco and drug use, age, and lengthy delay between times of original pain onset to SCS implant. ${ }^{30,33}$

Food and Drug Administration requirements for labeling the recent advanced iterations of SCS systems have led, for the first time, to Level I noninferiority comparative studies being undertaken to achieve labeling.

DRG SCS has been demonstrated as effective in multiple etiologies, including FBSS, CRPS, and chronic postsurgical pain. ${ }^{15} \mathrm{~A}$ recent study reported 1 year outcomes for $\mathrm{DRG}$ with overall pain scores reducing from 77.6 to $33.6(P<0.005)$. Back pain reduced from 74.5 to $39.7(P<0.05)$, and leg pain reduced from 74.6 to $28.7(P<0.0005)$. The most compelling pain reduction happened for foot pain with scores reducing from 81.4 to $22.0(P<0.05) .{ }^{15}$ Approximately $60 \%$ of the DRG SCS patients reported $>50 \%$ improvement in their pain, and the pain localized to the back, legs, and feet was reduced by $42 \%, 62 \%$, and $80 \%$, respectively. ${ }^{15}$ Other outcome parameters including quality of life, mood, and satisfaction were improved and maintained throughout the 12 months. ${ }^{15}$

The Accurate study is a US pivotal, noninferiority, randomized controlled trial (RCT) between DRG SCS and traditional SCS Medtronic system (Medtronic, Inc., Fridley, MN, USA). It is the largest RCT in the history of CRPS and causalgia, running from 2013 with primary completion estimated for 2018. The sample size for the study is 152 ; with 76 randomized to DRG SCS and 76 to the control arm using Medtronic traditional SCS. The inclusion criterion was leg pain for more than 6 months duration with a visual analog scale (VAS) score $>6 / 10 .{ }^{34}$

In the intention-to-treat analysis, superiority was demonstrated in the DRG SCS group with $81 \%$ of patients achieving $>50 \%$ pain reduction and meeting the primary endpoint at the 3-month mark, and 74\% maintaining that primary endpoint at 12-month follow-up. The traditional SCS arm demonstrated $56 \%$ of patients having $>50 \%$ pain reduction at 3 months and $53 \%$ maintaining this through 12 months. ${ }^{34}$
In the subset analysis of the implant-only group, the data were even more impressive with $93 \%$ of the DRG SCS group meeting the primary endpoint at 3 months and $86 \%$ at 12 months. The traditional SCS arm had $72 \%$ meeting the primary endpoint and $70 \%$ at 12 months. ${ }^{34}$ The statistical analysis demonstrated noninferiority and, beyond that, superiority in the intention-to-treat, modified intention-to-treat, and implant-only groups. Furthermore, it was noted that $70 \%$ of patients achieved $>80 \%$ pain reduction in the DRG group versus $52 \%$ in the Medtronic group. Target specificity for stimulation and pain relief was achieved in $94.5 \%$ of the DRG group and $61 \%$ of the Medtronic group. ${ }^{34}$

The Sunburst study is set to run from 2013, with primary completion in 2016. It is a prospective randomized, non-inferiority controlled trial with the St Jude Medical Company (St Jude Medical, Inc. St Paul, MN, USA). Patients with intractable pain were randomized for the order they would receive either traditional or burst SCS. The study was performed with a one-to-one crossover at 12 weeks to the alternate therapy. The outcome measures included safety, effectiveness, and non-inferiority. The study was applied to an enriched cohort with patients who required to have pre-existing pain scores $>6 / 10$ and a $>50 \%$ pain reduction in a traditional SCS trial using tonic stimulation. The sample size for the study was 121 with 100 people randomized. The sample size reported to date is 85 with a 24 -week follow-up. The mean age of patients was 59 years, with a median duration of pain being 13 years. ${ }^{35}$

The trial demonstrated noninferiority, and further statistical analysis demonstrated superiority for burst stimulation over tonic stimulation $(P=0.035) .{ }^{35}$ The mean difference in burst pain reduction compared with tonic stimulation was $6 \mathrm{~mm}$ VAS points. This difference, while being statistically significant, does not meet the well-defined criteria for minimal clinical important difference. ${ }^{36}$

Approximately $65 \%$ of the burst cohort experienced paresthesia-free stimulation and $69 \%$ of the cohort chose a preference for burst, with the majority of these having their preference related to no paresthesia, more so than better pain reduction. ${ }^{34}$

The Senza RCT is a Level I study design run from 2012 with an estimated primary completion in $2015 .^{22,37}$ This is the first-ever RCT of two SCS therapies with patients randomized to HF10 SCS (Senza System; Nevro Corp., Redwood City, CA, USA) or traditional SCS commercially available, Precision Plus, SCS system (Boston Scientific Corporation, Marlborough, MA, USA). It is a noninferiority study with the statistical capability of demonstrating superiority supervised by the Food and Drug Administration, and patients were monitored and programmed by the technicians associated with the respective devices. One hundred and ninety-eight 
patients were randomized with 101 to the HF10 SCS group and 97 to traditional. Of these, $90 \mathrm{HF} 10 \mathrm{SCS}$ patients and 81 traditional SCS patients were subsequently implanted.

The primary endpoint of $>50 \%$ back pain reduction at 3 months was achieved in $80.9 \%$ of the HF10 SCS group versus $42.5 \%$ of the traditional SCS group. ${ }^{37}$ This met the criteria for noninferiority and statistical superiority $(P<0.001)$. Furthermore, at 12 months, this primary endpoint was met in $78.7 \%$ versus $51.3 \%$ of the patients.

Similarly, the primary endpoint for leg pain reduction was met in $80.0 \%$ of the HF10 SCS group versus $49.4 \%$ of the traditional SCS group. ${ }^{37}$ The responder rates for $>50 \%$ leg pain reduction at 3 months was $83.1 \%$ in the HF10 SCS group and $55.0 \%$ in the traditional SCS group. The 12-month outcome data for the same groups were $78.7 \%$ versus $51.3 \%$ (superiority $P$ value, $P<0.001$ ). ${ }^{37}$ This study demonstrated superiority of HF10 SCS to traditional SCS in all primary and secondary endpoints that has led to the labeling of HF10 therapy as superior to traditional low-frequency SCS by the Food and Drug Administration.

In further analysis of pain etiology, it was demonstrated that for the conditions of FBSS, radiculopathy, degenerative disc disease, and spondylosis, the relative ratio of patients meeting the primary endpoint with HF10 SCS was approximately 2.0 times the traditional SCS (eg, FBSS $85.7 \%$ versus $41.4 \%$ ). ${ }^{37}$

Further subset analysis of patients who achieved VAS pain scores of $\leq 2.5$ showed that for those with back pain, relief was maintained for 12 months $68.5 \%$ of the time for HF10 SCS, but only $35.8 \%$ of the time using traditional SCS. Whereas, for those with leg pain it was achieved $67.4 \%$ of the time for HF10 SCS versus $42.5 \%$ of the time with traditional SCS. Superiority $P$-values for HF10 were significant $(P<0.001) .{ }^{37}$

These data demonstrate compelling evidence for treating complex back pain that was previously unheralded in the literature. Furthermore, paresthesia-free options allow the patient to keep stimulation on potentially 24 hours a day and hence sleep with the stimulator on and also perform activities such as driving.

\section{Economical or cost efficiency}

Health care policy and funding decisions require evidence of clinical efficacy and information around cost-effectiveness of treatments. ${ }^{38,39}$ Consequently, there have been a number of studies considering the economic factors associated with SCS. Most recently, a 2015 study investigating the cost-effectiveness of conventional medical management with or without SCS in patients with FBSS compared a summary of the total direct and indirect costs incurred in the 12 months prior and 24 months following SCS. ${ }^{40}$ The costs were scaled to values of $€ 2,009$. The total pre-SCS treatment costs were equivalent to $€ 6,567 /$ patient-year. The year of implant incurred a significant increase in costs of $€ 20,902$ /patient-year, mainly attributed to the high cost of the SCS devices. In the following 12-14 months, SCS implant had dropped to $€ 5,430$ /patient-year. ${ }^{40}$ Applying the current United Kingdom National Health Service threshold (intervention considered not cost-effective if the incremental cost-effectiveness ratio is higher than $€ 45,000$ /qualityadjusted life year [QALY]), SCS with conventional medical management would be considered cost-effective around $40 \%$ of the time. ${ }^{40}$ However, if the willingness-to-pay threshold was shifted to $€ 60,000 / \mathrm{QALY}$, SCS would be considered cost-effective by the National Health Service with an average of $80 \%$ of the time.

In 2013, a study developed models to evaluate the costeffectiveness of SCS and conventional medical management together compared with conventional medical management alone for patients with FBSS and CRPS. ${ }^{41}$ Health effects were expressed as QALYs and costs were expressed as Canadian dollars (CAN\$) scaled to 2012. The models were extrapolated over a 20 year-time period with $3.5 \%$ discounts annually (as per National Institute of Clinical Excellence suggestion). The modeling data showed that SCS with conventional medical management is cost-effective compared with conventional medical management alone for all presentations, with a cost-effectiveness ratio for SCS of CAN\$9293 for FBSS and CAN\$11,216 for CRPS per QALY gained. ${ }^{41}$

In a study in 2010, the cost-effectiveness of SCS with conventional medical management was compared with conventional medical management alone in CRPS patients. ${ }^{42}$ This study models economic costs using a simulated model population, employing parameters and assumptions set from previously published randomized trials. Here, SCS was shown to be cost-effective in select CRPS patients, with a probability exceeding $80 \%$ that SCS is cost-effective where the willingness to pay is set for a maximum of $£ 30,000$ per QALY. $^{42}$

Another cost-effectiveness study of SCS was performed in 2010 using a FBSS cohort. ${ }^{42}$ Here, the authors compared SCS versus conventional medical management versus reoperation. Rechargeable and nonrechargeable implantable pulse generators were also assessed for cost efficacy. This study showed that in selected patients, SCS is cost-effective both as an adjunct to conventional medical management and as an alternative to reoperation; that the likelihood SCS would be cost-effective versus conventional medical management and versus reoperation exceeds $80 \%$, where 
the willingness to pay is set for a maximum of $£ 20,000$ per QALY. $^{42}$

In 2008, a systematic review for cost-effectiveness of three studies where FBSS patients had been treated with SCS demonstrated that SCS is both more effective and less costly than conventional medical management alone in the long-term but there are high upfront implant costs associated with SCS implantation and maintenance. ${ }^{43}$

In 2008, another study reported the generic health-related quality of life and costs of SCS at 6 months follow-up (using data from the PROCESS trial) compared to the quality of life, resource consumption, and costs of conventional medical management alone in patients with FBSS. ${ }^{39}$ The study found that the mean total health care costs for the SCS group were significantly higher $(€ 12,653)$ than the conventional medical management group (€2,594), when scaled for UK 2005-2006 national data. ${ }^{39}$

This result reflects the high upfront costs of SCS over the limited 6-month follow-up period. The authors showed that $15 \%$ of the additional mean cost of SCS was offset within 6 months by a reduced use of drug and nondrug therapies. They also demonstrated a gain in quality of life over the same period which was significantly greater for the SCS group. The study concludes that, over the short term, SCS treatment results in greater healthcare costs but also generates important health improvements for the patients over the same period. ${ }^{39}$

Cost-efficacy studies show that despite significant initial costs, SCS compared with other conventional treatments available to chronic pain patients results in long-term reductions in health care costs, which offset the high initial treatment costs over time. ${ }^{44}$
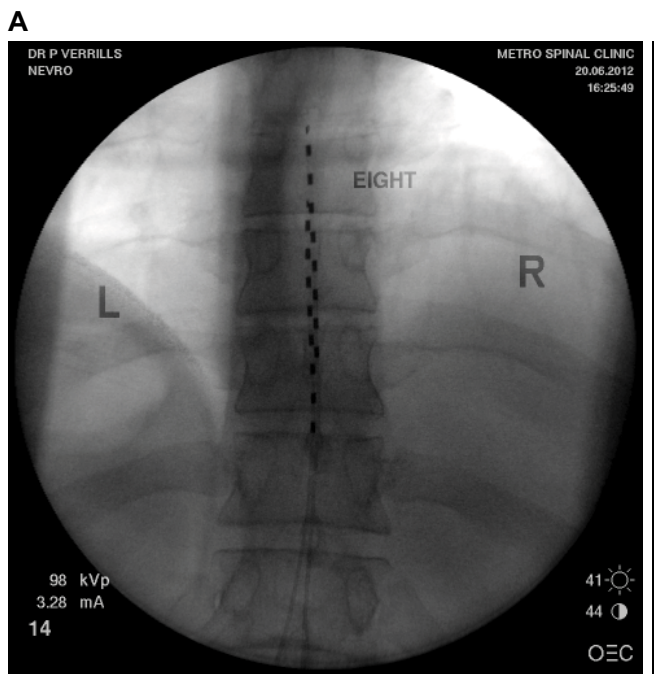

\section{Safety and tolerability}

In the literature, SCS is reported as a safe procedure due to its reversible and minimally invasive characteristics. ${ }^{30}$ Although catastrophic complications are possible, they are very rare. However, the incidence of minor complications of SCS has been reported at around $30 \%-40 \% .^{13,30,31,45-47}$ These minor complications tend to occur within 12 months of implantation and are readily reversible and generally resolved. ${ }^{13}$

The complications are divided into three main categories: mechanical, biological, and technique-related. ${ }^{32}$ Complications of a mechanical origin are more common than those of biological origin. ${ }^{31,45}$ Historically, hardware-related complications occurred at a rate of between $24 \%-50 \%$, whereas adverse biological events occurred in $7.5 \%$ of cases. ${ }^{30}$

Mechanical complications include lead fracture or disconnection, which has a reported incidence of between $5 \%$ and $9 \%$; lead migration has a reported incidence between $0 \%$ and $27 \%$; implantable pulse generator failure occurred at a reported frequency of $1.7 \% .{ }^{11,30}$ These complications can be minimized by using appropriate leads, anchoring, and suturing techniques. Furthermore, minimizing patient movements in the first 3 months after surgery allows for postoperative scarring of leads into place. ${ }^{30}$

Kapural et $\mathrm{al}^{22}$ demonstrated that lead migration of significance and requiring intervention in both the HF10 and traditional SCS arms occurred $<5 \%$. This most likely reflects improvements in both lead design and the anchoring systems used (Figures 1-3). 14,22,26,48

Biological complications include infection, allergic reaction, pain at implant site, implantable pulse generator seroma, epidural fibrosis, epidural hematoma, dural

B

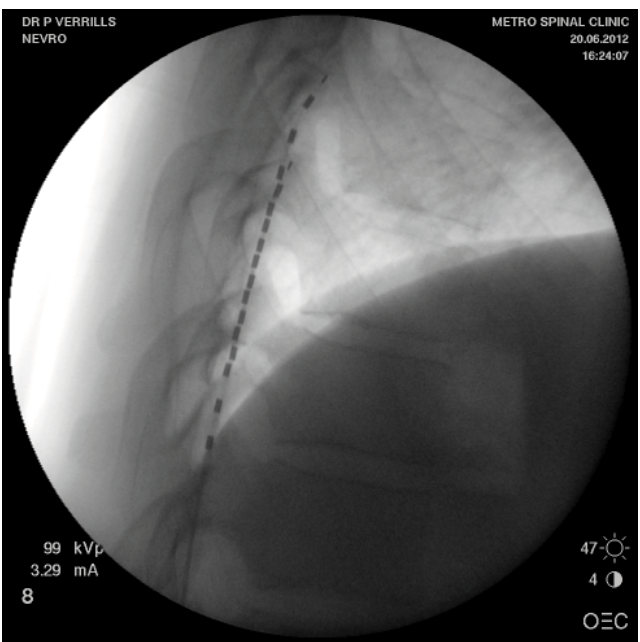

Figure I (A) Posterior anterior fluoroscopy image and (B) lateral fluoroscopy image of T8-TI0 placement of linear leads (Nevro Corp.) for the treatment of chronic back and leg pain.

Note: Images courtesy of Metro Pain Group.

Abbreviations: L, left; R, right. 


\section{A}

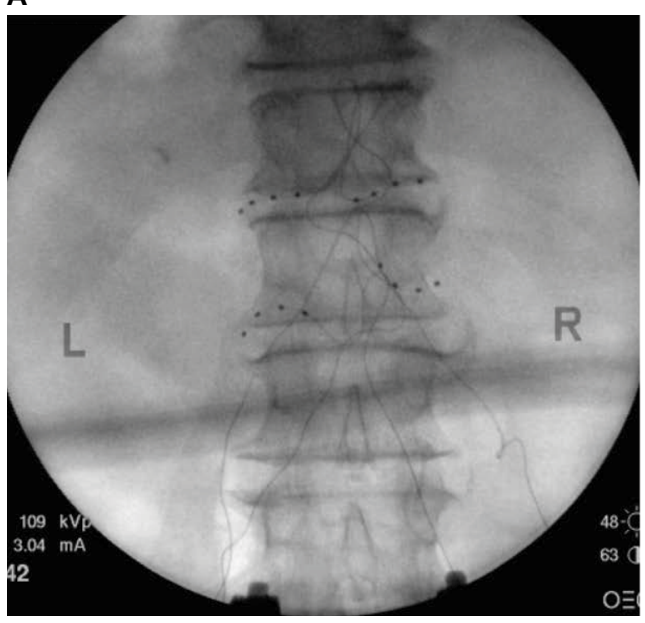

B

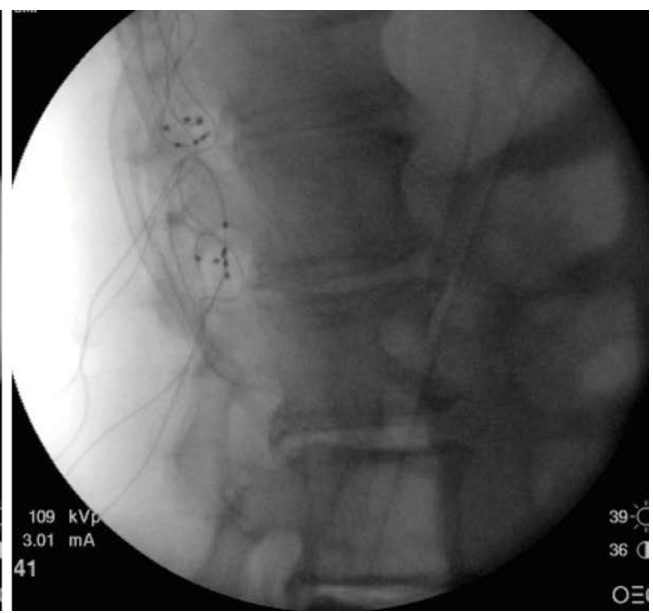

Figure 2 (A) Posterior anterior fluoroscopy image and (B) lateral fluoroscopy image of leads placed bilaterally at TI2 and LI dorsal root ganglions for the treatment of chronic idiopathic orchialgia pain.

Note: Images courtesy of Metro Pain Group.

Abbreviations: L, left; $R$, right.

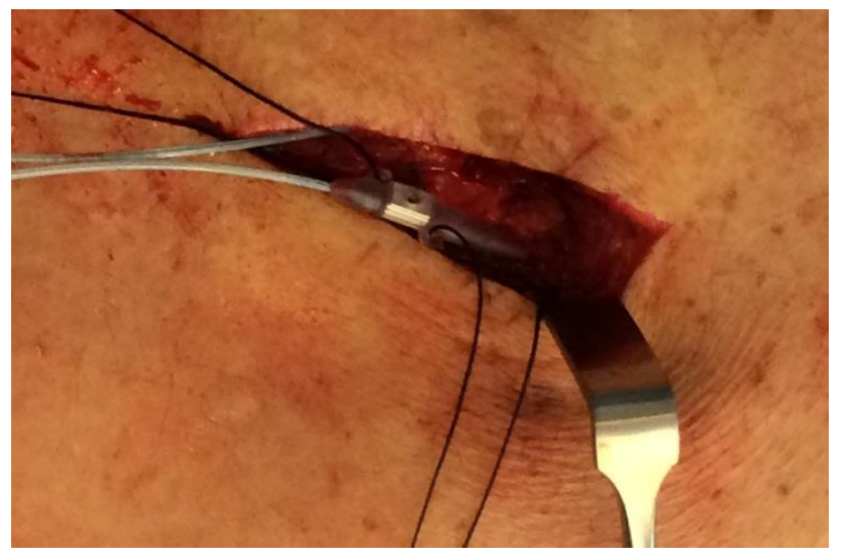

Figure 3 Intraoperative image of NX3000 anchor system by Nevro Corp. Note: Images courtesy of Gillian Nowesenitz.

puncture, and, rarely, neurological injury..$^{30,31,49-52,57-60}$ The most common biological complication is infection with a rate between $3 \%$ and $8 \%$, and the majority of these are superficial. ${ }^{30}$ As is seen in the more recent literature, ${ }^{30}$ incidence of infection can be minimized via pre and postoperative antibiotic use and appropriate skin preparation. The occurrence of dural puncture is reported as between $0.3 \%$ and $2 \% .^{53}$ Other adverse biological events such as epidural fibrosis, compressive phenomenon, or spinal cord injury, while serious, are rare.

The Neuromodulation Appropriateness Consensus Committee has recommended a number of criteria and adaptations to practice to help reduce complications: physician training and mentoring, the appropriate and careful selection of patients, a continued focus on equipment development and innovation, as well as the dissemination and application of practice and research-based advances. ${ }^{30}$

\section{Patient-focused perspectives}

As this field strives to provide high-quality, transparent, and independent empirical evidence for SCS therapies, it is possible to overlook the primary rationale for SCS treatment in the first place: patient benefit.

Patients suffering from chronic pain are often misdiagnosed or treated inappropriately. Improvements to training in pain management are needed, beginning at the undergraduate medical level. At present, the time allocated to pain management is generally inadequate; for instance, in the United Kingdom, the median time spent on pain management by a medical student is 13 hours, and sometimes it is as little as 6 hours. ${ }^{2}$ Indeed, when

\footnotetext{
"the undergraduate training of all healthcare professionals is analyzed, education about the identification, assessment, and treatment of pain represents less than $1 \%$ of universitybased teaching - yet pain is the most common reason for patients to consult their general practitioner."
}

The ensuing repercussions may include inadequate diagnosis, inappropriate treatments, and extended periods of mismanagement. Further complicating the treatment of this cohort has been the inclusion of neuromodulation therapies as a treatment of last resort. ${ }^{54}$ Yet research has shown that shifting SCS forward in the treatment algorithm of refractory chronic pain is associated with better patient outcomes. ${ }^{44,55}$

In recent years, many researchers and practitioners have included patient satisfaction (alongside empirical measures) as a clinically useful metric for assessing SCS treatment success. ${ }^{23}$ When reported, overall patient satisfaction is high for the vast majority of SCS patients, perhaps reflecting the efficacy of SCS treatment, but may also reflect factors such 
as limitations of alternative treatments, safety, and tolerability of SCS and the rapidity of onset and durability of SCS treatment. ${ }^{56}$

Moreover, under current arrangements, most patients access SCS treatment through private health insurance schemes or through compensatory bodies such as workers compensation schemes.$^{57}$ For patients who do not qualify for these funding systems, the immediate cost outlay would likely post a significant financial barrier to treatment. ${ }^{57}$ The SCS specialty should aim to support the provision of equitable and accessible treatment for all.

\section{Conclusion}

Significant evidence exists for traditional SCS as a safe, clinical, and cost-effective treatment for many chronic pain conditions. Indeed, the field is rapidly evolving, and there is now Level I evidence for newer techniques including HF10 SCS and DRG SCS, which demonstrate dramatic improvements in overall efficacy in reducing pain in specific conditions, including failed back surgery, back pain, neuropathic leg pain, CRPS, and causalgia.

Furthermore, the field has increasingly met the challenge of not only having newer devices to achieve these outcomes but concurrently reducing the risks of complications and adverse events.

The data supporting SCS in its multiple forms are compelling and have reached a level that now demands that this therapy be considered earlier in the treatment continuum and to be no longer regarded as simply an end-stage salvage therapy.

\section{Acknowledgment}

The authors wish to thank anonymous reviewers for constructive comments that have led to an improved paper.

\section{Disclosure}

Paul Verrills is a consultant to NEVRO Corp and St Jude Medical Advisory and peer to peer teaching. The other authors (AB and CS) declare no conflicts of interest.

\section{References}

1. Elzahaf RA, Tashani OA, Unsworth BA, Johnson MI. The prevalence of chronic pain with an analysis of countries with a human development index less than 0.9: a systematic review without meta-analysis. Curr Med Res Opin. 2012;28(7):1221-1229.

2. Pergolizzi J, Ahlbeck K, Aldington D, et al. The development of chronic pain: physiological CHANGE necessitates a multidisciplinary approach to treatment. Curr Med Res Opin. 2013;29(9):1127-1135.

3. Langley PC. The prevalence, correlates and treatment of pain in the European Union. Curr Med Res Opin. 2011;27(2):463-480.

4. McBeth J, Jones K. Epidemiology of chronic musculoskeletal pain. Best Pract Res Clin Rheumatol. 2007;21(3):403-425.
5. Merskey H, Bogduk N. Classification of Chronic Pain: Descriptions of Chronic Pain Syndromes and Definitions of Pain Terms. Seattle: IASP Press; 1994.

6. Hauser W, Bock F, Engeser P, Tolle T, Willweber-Strumpfe A, Petzke F. Long-term opioid use in non-cancer pain. Dtsch Arztebl Int. 2014; 111(43):732-740.

7. Shealy CN, Mortimer JT, Reswick JB. Electrical inhibition of pain by stimulation of the dorsal columns: preliminary clinical report. Anesth Analg. 1967;46(4):489-491.

8. Deer TR, Mekhail N, Provenzano D, et al. The appropriate use of neurostimulation of the spinal cord and peripheral nervous system for the treatment of chronic pain and ischemic diseases: the Neuromodulation Appropriateness Consensus Committee. Neuromodulation. 2014;17(6):515-550.

9. Song JJ, Popescu A, Bell RL. Present and potential use of spinal cord stimulation to control chronic pain. Pain Physician. 2014;17(3):235-246.

10. Roulaud M, Durand-Zaleski I, Ingrand P, et al. Multicolumn spinal cord stimulation for significant low back pain in failed back surgery syndrome: design of a national, multicentre, randomized, controlled health economics trial (ESTIMET Study). Neurochirurgie. 2015;61(1):20.

11. Cameron T. Safety and efficacy of spinal cord stimulation for the treatment of chronic pain: a 20-year literature review. J Neurosurg. 2004; 100(3 Suppl):254-267.

12. Deer T, Kim C, Bowman R, Ranson M, Douglas CS, Tolentino W. Spinal cord stimulation as a method of reducing opioids in severe chronic pain: a case report and review of the literature. $W V$ Med J. 2010;106(4 Spec No): $56-59$.

13. Turner JA, Loeser JD, Deyo RA, Sanders SB. Spinal cord stimulation for patients with failed back surgery syndrome or complex regional pain syndrome: a systematic review of effectiveness and complications. Pain. 2004;108(1-2):137-147.

14. Deer TR, Krames E, Mekhail N, et al. The appropriate use of neurostimulation: new and evolving neurostimulation therapies and applicable treatment for chronic pain and selected disease states. Neuromodulation. 2014;17(6):599-615.

15. Liem L, Russo M, Huygen FJ, et al. One-year outcomes of spinal cord stimulation of the dorsal root ganglion in the treatment of chronic neuropathic pain. Neuromodulation. 2015;18(1):41-48.

16. De Ridder D, Plazier M, Kamerling N, Menovsky T, Vanneste S. Burst spinal cord stimulation for limb and back pain. World Neurosurg. 2013; 80(5):642-649.

17. De Ridder D, Vanneste S, Plazier M, van der Loo E, Menovsky T. Burst spinal cord stimulation: toward paresthesia-free pain suppression. Neurosurgery. 2010;66(5):986-990.

18. Van Buyten JP, Al-Kaisy A, Smet I, Palmisani S, Smith T. Highfrequency spinal cord stimulation for the treatment of chronic back pain patients: results of a prospective multicenter European clinical study. Neuromodulation. 2013;16(1):59-65.

19. Tiede J, Brown L, Gekht G, Vallejo R, Yearwood T, Morgan D. Novel spinal cord stimulation parameters in patients with predominant back pain. Neuromodulation. 2013;16(4):370-375.

20. Shanthanna H, Chan P, McChesney J, Paul J, Thabane L. Assessing the effectiveness of "pulse radiofrequency treatment of dorsal root ganglion" in patients with chronic lumbar radicular pain: study protocol for a randomized control trial. Trials. 2012;13:52.

21. Wall PD, Devor M. Sensory afferent impulses originate from dorsal root ganglia as well as from the periphery in normal and nerve injured rats. Pain. 1983;17(4):321-339.

22. Kapural L, Yu C, Doust MW, et al. Novel 10-kHz High-frequency therapy (HF10 therapy) is superior to traditional low-frequency spinal cord stimulation for the treatment of chronic back and leg pain: the SENZA-RCT randomized controlled trial. Anesthesiology. 2015; 123(4):851-860.

23. Grider JS, Manchikanti L, Carayannopoulos A, et al. Effectiveness of spinal cord stimulation in chronic spinal pain: a systematic review. Pain Physician. 2016;19(1):E33-E54. 
24. de Vos CC, Bom MJ, Vanneste S, Lenders MW, de Ridder D. Burst spinal cord stimulation evaluated in patients with failed back surgery syndrome and painful diabetic neuropathy. Neuromodulation. 2014; 17(2):152-159.

25. Taylor RS, Desai MJ, Rigoard P, Taylor RJ. Predictors of pain relief following spinal cord stimulation in chronic back and leg pain and failed back surgery syndrome: a systematic review and meta-regression analysis. Pain Pract. 2014;14(6):489-505.

26. Geurts JW, Smits H, Kemler MA, Brunner F, Kessels AGH, van Kleef M. Spinal cord stimulation for complex regional pain syndrome type I: a prospective cohort study with long-term follow-up. Neuromodulation. 2013;16(6):523-529.

27. Perruchoud C, Eldabe S, Batterham AM, et al. Analgesic efficacy of high-frequency spinal cord stimulation: a randomized double-blind placebo-controlled study. Neuromodulation. 2013;16(4):363-369.

28. Barolat G, Oakley JC, Law JD, North RB, Ketcik B, Sharan A. Epidural spinal cord stimulation with a multiple electrode paddle lead is effective in treating intractable low back pain. Neuromodulation. 2001 4(2):59-66.

29. Russo M, Verrills P, Mitchell B, Salmon J, Barnard A, Santarelli D. High frequency spinal cord stimulation at $10 \mathrm{kHz}$ for the treatment of chronic pain: 6-month Australian clinical experience. Neuromodulation. Pain Physician. 2016;19(4):267-280.

30. Deer TR, Mekhail N, Provenzano D, et al. The appropriate use of neurostimulation: avoidance and treatment of complications of neurostimulation therapies for the treatment of chronic pain. Neuromodulation. 2014;17(6):571-598.

31. Hayek SM, Veizi E, Hanes M. Treatment-limiting complications of percutaneous spinal cord stimulator implants: a review of eight years of experience from an academic center database. Neuromodulation. 2015 ; 18(7):603-608.

32. Kumar K, Wilson JR, Taylor RS, Gupta S. Complications of spinal cord stimulation, suggestions to improve outcome, and financial impact. $J$ Neurosurg Spine. 2006;5(3):191-203.

33. De La Cruz P, Fama C, Roth S, et al. Predictors of spinal cord stimulation success. Neuromodulation. 2015;18(7):599-602.

34. Levy R. Plenary presentation. Paper presented at: 19th Annual North American Neuromodulation Society (NANS); 2015; Las Vegas, NV.

35. Deer T. Plenary presentation. Paper presented at: 19th Annual North American Neuromodulation Society (NANS); 2015; Las Vegas, NV.

36. Farrar JT, Portenoy RK, Berlin JA, Kinman JL, Strom BL. Defining the clinically important difference in pain outcome measures. Pain. 2000;88(3):287-294.

37. Kapural L. Comparison of $10 \mathrm{kHz}$ high-frequency SCS to traditional low-frequency SCS: the SENZA-RCT U.S. Pivotal Study. North American Neuromodulation Society (NANS); 2014; Las Vegas, NV.

38. North RB, Shipley J, Wang H, Mekhail N. A review of economic factors related to the delivery of health care for chronic low back pain. Neuromodulation. 2014;17:69-76.

39. Manca A, Kumar K, Taylor RS, et al. Quality of life, resource consumption and costs of spinal cord stimulation versus conventional medical management in neuropathic pain patients with failed back surgery syndrome (PROCESS trial). Eur J Pain. 2008;12(8) 1047-1058.

40. Zucco F, Ciampichini R, Lavano A, et al. Cost-effectiveness and costutility analysis of spinal cord stimulation in patients with failed back surgery syndrome: results from the PRECISE study. Neuromodulation. 2015;18(4):266-276.

41. Kumar K, Rizvi S. Cost-effectiveness of spinal cord stimulation therapy in management of chronic pain. Pain Med. 2013;14(11): 1631-1649.

42. Kemler MA, Raphael JH, Bentley A, Taylor RS. The cost-effectiveness of spinal cord stimulation for complex regional pain syndrome. Value Health. 2010;13(6):735-742.
43. Bala MM, Riemsma RP, Nixon J, Kleijnen J. Systematic review of the (cost-)effectiveness of spinal cord stimulation for people with failed back surgery syndrome. Clin J Pain. 2008;24(9):741-756.

44. Lad SP, Petraglia Iii FW, Kent AR, et al. Longer delay from chronic pain to spinal cord stimulation results in higher healthcare resource utilization. Neuromodulation. 2016;29(10):12389.

45. Eldabe S, Buchser E, Duarte RV. Complications of spinal cord stimulation and peripheral nerve stimulation techniques: a review of the literature. Pain Med. Epub 2015 Dec 14.

46. Petraglia FW 3rd, Farber SH, Gramer R, et al. The incidence of spinal cord injury in implantation of percutaneous and paddle electrodes for spinal cord stimulation. Neuromodulation. 2016;19(1):85-90.

47. Kumar K, Taylor RS, Jacques L, et al. Spinal cord stimulation versus conventional medical management for neuropathic pain: a multicentre randomised controlled trial in patients with failed back surgery syndrome. Pain. 2007;132(1-2):179-188.

48. Mironer YE, Satterthwaite JR, Lewis EM, et al. Efficacy of a single,

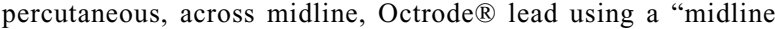
anchoring" technique in the treatment of chronic low back and/ or lower extremity pain: a retrospective study. Neuromodulation. 2008;11(4):286-295.

49. Lennarson PJ, Guillen FT. Spinal cord compression from a foreign body reaction to spinal cord stimulation: a previously unreported complication. Spine. 2010;35(25):E1516-E1519.

50. Levy R, Henderson J, Slavin K, et al. Incidence and avoidance of neurologic complications with paddle type spinal cord stimulation leads. Neuromodulation. 2011;14(5):412-422.

51. Deer TR, Levy RM, Verrills P, Mackey S, Abejon D. Perspective: peripheral nerve stimulation and peripheral nerve field stimulation birds of a different feather. Pain Medicine. 2015;16(3):411-412.

52. Scranton RA, Skaribas IM, Simpson RK Jr. Spinal stimulator peri-electrode masses: case report. J Neurosurg Spine. 2015;22(1): 70-74.

53. Deer TR, Stewart CD. Complications of spinal cord stimulation: identification, treatment, and prevention. Pain Medicine. 2008;9(S1): S93-S101.

54. Krames ES. Interventional pain management. Appropriate when less invasive therapies fail to provide adequate analgesia. Med Clin North Am. 1999;83(3):787-808.

55. Kumar K, Rizvi S, Bnurs SB. Spinal cord stimulation is effective in management of complex regional pain syndrome I: fact or fiction. Neurosurgery. 2011;69(3):566-580.

56. Kumar K, Taylor RS, Jacques L, et al. The effects of spinal cord stimulation in neuropathic pain are sustained: a 24-month followup of the prospective randomized controlled multicenter trial of the effectiveness of spinal cord stimulation. Neurosurgery. 2008;63(4):762-770.

57. Ellery B, Parsons J, Merlin T. High Frequency Spinal Cord Stimulation and Dorsal Root Ganglion Stimulation for Chronic Pain. Herston QLD: Department of Health, Queensland; 2015.

58. Kemler MA, De Vet HCW, Barendse GAM, Van Den Wildenberg FAJM, Van Kleef M. The effect of spinal cord stimulation in patients with chronic reflex sympathetic dystrophy: two years' follow-up of the randomized controlled trial. Ann Neurol. 2004;55(1):13-18.

59. North RB, Kidd DH, Farrokhi F, Piantadosi SA. Spinal cord stimulation versus repeated lumbosacral spine surgery for chronic pain: a randomized, controlled trial. Neurosurgery. 2005;56(1):98-106.

60. Turner JA, Hollingworth W, Comstock B, Deyo RA. Comparative effectiveness research and policy: experiences conducting a coverage with evidence development study of a therapeutic device. Med Care. 2010;48(6 Suppl):S129-S136.

61. Turner JA, Hollingworth W, Comstock BA, Deyo RA. Spinal cord stimulation for failed back surgery syndrome: outcomes in a workers' compensation setting. Pain. 2010;148(1):14-25. 
62. de Vos CC, Dijkstra C, Lenders MWPM, Holsheimer J. Spinal cord stimulation with hybrid lead relieves pain in low back and legs. Neuromodulation. 2012;15(2):118-123.

63. Moriyama K, Murakawa K, Uno T, et al. A prospective, open-label, multicenter study to assess the efficacy of spinal cord stimulation and identify patients who would benefit. Neuromodulation. 2012; 15(1):7-12.
64. Al-Kaisy A, Van Buyten JP, Smet I, Palmisani S, Pang D, Smith T. Sustained effectiveness of $10 \mathrm{kHz}$ high-frequency spinal cord stimulation for patients with chronic, low back pain: 24-month results of a prospective multicenter study. Pain Med. 2014;15(3):347-354.

65. De Ridder D, Lenders MW, De Vos CC, et al. A 2-center comparative study on tonic versus burst spinal cord stimulation: amount of responders and amount of pain suppression. Clin J Pain. 2015;31(5):433-437.

\section{Publish your work in this journal}

The Journal of Pain Research is an international, peer reviewed, open access, online journal that welcomes laboratory and clinical findings in the fields of pain research and the prevention and management of pain. Original research, reviews, symposium reports, hypothesis formation and commentaries are all considered for publication.
Dovepress

The manuscript management system is completely online and includes a very quick and fair peer-review system, which is all easy to use. Visit http://www.dovepress.com/testimonials.php to read real quotes from published authors. 